Journal of Animal and Feed Sciences, 7, 1998, $65-78$

\title{
Regulatory peptides in milk, food and in the gastrointestinal lumen of young animals and children
}

\author{
R. Zabielski \\ Department of Animal Physiology, Warsaw Agricultural University \\ Nowoursynowska 166, 02-787 Warsaw, Poland
}

\begin{abstract}
The present article reviews recent advances in our understanding of the regulatory role played by milk in the physiology of the neonate. Importance of milk bioactive proteins and peptides (BAPP) and their endogenous counterparts (hormones, gut regulatory peptides, growth factors) in the regulation of the development of the gastrointestinal tract (GIT) structure and function in the new-born is discussed. Mother's milk is often replaced with a milk formula that contains little or no BAPP. Although deprivation of milk BAPP is not lethal to the neonate, it affects GIT development processes, produces noticeable reduction of animal performance and lowers the resistance to GIT disorders. It is recommended that either the industrial processing is modified so as to avoid BAPP degradation or that the commercial milk formulas and weaning feeds should be supplemented with BAPP.
\end{abstract}

KEY WORDS: regulatory peptides, milk, food, young animals, children

\section{LIST OF ABBREVIATIONS}

ANP, atrial natriuretic peptide; BAPP, bioactive proteins and peptides; CCK, cholecystokinin; CDGF, colostrum-derived growth factor; EGF, epidermal growth factor; ET-1, endothelin-1; G17, G 34, gastrin-17 and -34; GIT, gastrointestinal tract; IgA, immunoglobulin A; IGF (-I, -II or $-1,-2)$, insulin-like growth factors; MAF, milk antiproliferative factor; MDGI, mammary-derived growth inhibitor; PYY, polypeptide YY; TGF (-a, -b), transforming growth factor; VIP, vasoactive intestinal polypeptide. 


\section{INTRODUCTION}

Colostrum and milk provide the new-born mammal with more than 2000 molecules which cover the nutritional requirements of the young, intensively growing organism. Among them, milk proteins are the major components responsible for the high nutritive value of milk. In addition to the nutritional aspect, milk proteins and peptides possess certain biological, e.g. growth stimulating, regulatory, antiinfectious, immunomodulating and enzymatic activities. Milk therefore provides an important link in the mother-offspring interaction during early postnatal life. Present animal production tends, however, to early-wean the offspring (pig production) or to replace mother's milk with artificial milk formulas (dairy cattle). In human infant nutrition both of these tendencies can also be observed. Simultaneously, more attention is being paid to feed supplementation for young animal and human infant nutrition. Feed supplementation aims to improve the function of the gastrointestinal tract (GIT) - which plays a central role in the development and health of young animals. Certain bioactive milk components could be potentially used as such feed supplements. This paper will briefly review the most recent knowledge concerning the presence of bioactive proteins and polypeptides (BAPP) found in milk, the role played by BAPP in the GIT and peripheral tissues in young animals, and discuss the question of supplementation of industrial feeds with BAPP.

\section{BIOACTIVE PROTEINS AND PEPTIDES IN COLOSTRUM AND MILK}

Mother's colostrum and milk contain a large variety of bjologically active proteins and peptides that are synthesised in the mammary gland and/or are extracted from the mother's blood (Table 1). Some of these proteins and all polypeptides are biologically active in milk (hormones, gut regulatory peptides, growth factors, enzymes, immunoglobulins, mucins) whilst the other proteins become active in the gastrointestinal tract as a result of their enzymatic digestion (e.g., caseins and their derived peptides). Bioactive milk components, being the product of milk protein digestion, were recently the subject of several extensive reviews by Wong et al. (1996), Mcisel (1997), Rudloff and Kunz (1997), Schanbacher et al. (1997), Tirelli et al. (1997), and therefore will be only briefly mentioned in the section concerning processing of milk. Milk immunoglobulins are reviewed in this issue by Grongnet and Duvaux-Ponter (1998).

Proteins and peptides found in a biologically active form in milk include protein hormones (insulin, somatostatin, prolactin), gut regulatory polypeptides (gastrin, CCK, VIP, bombesin, neurotensin) and growth factors (EGF, IGF-1, TGF). They are structurally identical and manifest similar biological activities to those found in the blood and gastrointestinal tissues of the mother and offspring. The list 
Biologically active proteins and peptides in milk

Proteins and peptides present in active form

Hormones

prolactin, somatostatin, growth hormone, growth hormone-releasing factor, calcitonin, insulin, thyroxin, oxytocin, melatonin, ANP, ET-1

Regulatory peptides gastrin, bombesin, CCK, VIP, neurotensin, delta sleep inducing peptide

Growth factors

EGF-I and -II, IGF, nerve growth factor, TGF- $\alpha$ and $-\beta$, platelet-derived growth factor, $\mathrm{CDGF}$

Mammary gland

inhibitors

mammastatin, MDGI, MAF

Enzymes

amylase, serum-sensitive lipase

Immunoglobulins

$\lg \mathrm{A}, \operatorname{IgG}, \operatorname{IgM}$

Glycoproteins

lactoferrin, milk mucins (e.g., mannose containing glycoproteins), adhesion molecules

Protein precursors bioactive substances resulting from the digestion of milk proteins

Casein

$\alpha$ and $\beta$-casein fragments - casomorphins, caseinophosphopeptides, immunopeptides, casokinins

$\kappa$-casein fragments - casoxins, casoplatenins

Whey protein $\quad \alpha$-lactoglobulin fragments $-\alpha$-lactophorins

$\beta$-lactoglobulin fragments $-\beta$-lactophorins

Lactoferrin lactoferroxins

Lactoalbumins lactorphins

is probably not yet closed. Indeed, a novel colostrum-derived growth factor (CDGF) has recently been isolated from porcine colostrum (Kelly and Coutts, 1997). Besides these apparently pro-trophic factors, there are several inhibitors in milk that control the growth, differentiation and regression of the mammary gland, e.g. mammastatin (Erwin et al., 1989), mammary-derived growth inhibitor, MDGI (Brandt et al., 1987), and milk antiproliferative factor, MAF (Toth et al., 1992). Transforming growth factor- $\beta$ (TGF- $\beta$ ), an inhibitor of mammary cell growth (Silberstein and Daniel, 1987), has been suggested to counteract TGF- $\alpha$ and EGF during growth and development of the mammary gland in mice. The biological role of milk inhibitory peptides in the offspring remains unknown. Milk enzymes (amylase, serum-sensitive lipase) and glycoprotein mucins, which prevent microbial adherence in the gut epithelium (for references sec: Rudloff and Kunz, 1997), may also be considered BAPP. Milk components can further enhance the bioactivity of BAPP or protect them from degradation in the GIT lumen. Rat milk protects so- 
matostatin in the gut and facilitates its absorption in a biologically active form (Rao et al., 1990). Defatted porcine colostrum or its components, the casein or acid-soluble fractions, protect gastrin and EGF from degradation during incubation with intestinal fluids (Shen and Xu, 1996; Xu et al., 1996).

The majority of bioactive peptides are present in milk at concentrations considerably higher than those found in maternal blood or in the tissues of the offspring. As an example, the insulin and bombesin concentrations in milk are 100 times greater than in the maternal blood plasma (Ballard et al., 1982; Weström et al., 1987). Concentrations of most bioactive peptides, however, are not constant and are usually higher during the first few days of lactation; e.g., neurotensin and endothelin-1 (ET-1) concentrations are initially more than 10 times higher than in the maternal and offspring blood plasma but they gradually decline with duration of lactation (Weström et al., 1987; Ken-Dror et al., 1997). There are also exceptions. Thus, atrial natriuretic peptide (ANP) is present in human colostrum and milk at the concentrations observed in the mother's blood and the concentration does not change during lactation (Ken-Dror et al., 1997). In rodents, the peak concentrations of bioactive peptides are observed in mid-lactation $(\mathrm{Xu}, 1996)$. The concentration of inhibitory polypeptides in milk (mammostatin, MDGI, MAF) increases in the late period of lactation (Brandt et al., 1987; Erwin et al., 1989; Toth et al., 1992).

The concentration of BAPP in colostrum and milk is also species specific, e.g. human and sow colostrum and milk is rich in EGF, whereas cow and rat colostrum and milk contain little EGF (Read et al., 1984; Jaeger et al., 1987; Raadberg et al., 1990; Iacopetta et al., 1992). In contrast, cow colostrum and milk are several times richer in insulin, IGF-I and IGF-II, and poorer in lysozyme compared to human (Ballard et al., 1982; Baxter et al., 1984; Ekman et al., 1985; Malven et al., 1987). This raises the problem of replacing maternal milk with artificial formulas which are usually based on cow milk.

The function of most milk bioactive peptides remains unclear, and a few explanations could be considered. On the one hand, colostrum and milk may be a convenient way of biological clearance from the maternal organism. This concerns especially the hormones and growth factors which are intensively cxtracted from the circulating blood, or synthesised in the mammary tissues, during late pregnancy and early lactation periods and are involved in the development of the mammary gland (prolactin, EGF, insulin) (Weström ct al., 1987; Grosvenor et al., 1992). Exclusively cleared substances could be of less relevance for the milk formula industry. On the other hand, colostrum and milk BAPP may support the induction and further regulation of the development of the gastrointestinal tract structure and function of the nconate. This may explain a higher concentration of certain hormones and growth factors at the beginning of lactation. During the first days after parturition, high concentrations of insulin and IGF-1 in colostrum and milk coincide with intensive growth of the intestinal mucosa and pancreas tissue; colostral 
insulin may be an important regulator of macromolecular transmission and gut closure (Svendsen ct al., 1986; Read, 1988). At that time, these peptides might carry out a double function in the neonate, i.e. stimulate gut endocrine system development as well as transiently regulate GIT activity until the neonate's own endocrine system begins to function. This phenomenon can be somehow homologous to the delivery of colostral immunoglobulins and the development of the gut immune system. On the way, there may be several important links between BAPP and the immune system, e.g. TGF- $\beta$ in bovine milk may mediate the primary immune response initiating secretion of IgA in the GIT of the new-born calves (Berthon and Salmon, 1993). Certain BAPP may also be involved in the endocrine type of communication between mother and suckling young, thus affecting the functions of the neonate far beyond the "gut barrier". As an example, the levels of thyroxin in the milk are influenced by the status of the thyroid gland of the lactating rat, and consequently reflect the thyroxin concentration in the blood of the suckling offspring (Strbak et al., 1980; Koldowsky et al., 1995). A substantial part of circulating prolactin in rat neonates is delivered in milk, since rat neonates secrete relatively little prolactin (Grosvenor et al., 1992). ANP and ET-1 are recent cxamples that presumably fulfil all the above mentioned functions: they are important systemic regulators of blood pressure and flow, natriuresis and diuresis in the mother and neonate, and are local stimulators of the development of mammary gland and lactogenesis in the mother as well as gut motility in the neonate (Lam et al., 1991; Ken-Dror et al., 1997).

\section{BAAP IN MILK FORMULAS}

Processing of milk (e.g., short lasting heating) increases protein digestibility and reduces bacterial contamination, therefore from the classical nutritional point of view it may be considered beneficial. On the other hand, heating manifests certain unfavourable influences on amino acids and sugars. It has also been reported that the ability of protein to bind minerals is reduced by heating (Rudloff and Lonerdal, 1992a). Milk sterilisation, and to a lesser degree the UHT (ultra-hightemperature) process, reduces the digestibility of milk proteins by modification of the secondary and tertiary structure of protein molecules (Rudloff and Lönnerdal, 1992b; Rudloff and Kunz, 1997).

The biological activity of peptides in processed milk depends on the parameters of the technological process (duration and temperature), and the bioactive peptides in milk are much more susceptible to lose their activity than the BAPP derived from milk protein precursors. Caseins, lactoferrin and whey proteins are thermosensitive although they retain some of their activity after sterilisation of milk (Murakami, 1989). Presumably the prior binding of the ligand increases the 
termoresistance of the protein-ligand complex (Puyol et al., 1994). Heating modifies the structure of proteins, thus whey protein is glycosylated in the presence of milk sugars (McCrae and Muir, 1995), and the products manifest similar biological activity to glycoproteins (Vardri, 1993; Guimont et al., 1997). On the other hand, heating inactivates all lysozyme $\left(>62.5^{\circ} \mathrm{C}\right)$ and most milk enzymes $\left(>70^{\circ} \mathrm{C}\right)$ and immunoglobulins $\left(>72^{\circ} \mathrm{C}\right)$ (Björksten et al., 1980; Odumodu et al., 1993). Pastcurised cow milk contains much less EGF than fresh cow milk (Read et al., 1985). Prolactin concentration is reduced but detectable in the whey of pasteurised milk but not in milk pasteurised and fermented using yoghurt lactic acid bacteria. Bombesin, insulin, TGF- $\beta 2$ and NGF are detectable in boiled or pasteurised milk and pasteurised whey although in much lower concentrations than in fresh milk or colostrum (Guimont et al., 1997). The concentrations of EGF and IGF-I in infant formulas based on bovine milk are low or undetectable (Read et al., 1985; Nagashima et al., 1990). While reviewing the literature for this article no information was found concerning production on a commercial scale of an artificial milk formula supplemented with BAPP.

\section{BIOACTIVE PROTEIN AND PEPTIDES IN THE GASTROINTESTINAL TRACT}

Gastrin was the first regulatory peptide to be detected in the lumen of the stomach in adult human subjects (Jordan and Yip, 1972). Since then many regulatory peptides have been found in the GIT lumen (Rao, 1991). Luminal gastrin, somatostatin, secretin, CCK, substance P and PYY originate from the endocrine cells in the intestinal mucosa (Miller et al., 1980; Sninsky ct al., 1984; Kuvishnoff et al., 1991; Rao, 1991), and substantial amounts of insulin and somatostatin arrive at the duodenum within the pancreatic juice (Conlon et al., 1979). Saliva is the main source of growth factors (EGF, IGF) and neuropeptides (substance P, neurokinin A, calcitocin gene-related peptide, neuropeptide $\mathrm{Y}$, and vasoactive intestinal polypeptide) in the GlT lumen (Rao, 1991; Dawidson et al., 1997). The route by which gut peptides produced in the endocrine cells enter the duodenal lumen is not yet completely understood. Fujimiya et al. (1995) showed that enterochromaffin cells actively relcase serotonin into the lumen of the small intestine, and the ratio of luminal content to tissue content is higher in embryonic and nconatal gut compared to the gut of adult rats. Okumiya et al. (1996), in an immuno-electron microscopic study, demonstrated changes in the subcellular localisation of gastrin granules (migration from basal to apical rcgions) and gastrin release into the small intestinal lumen induced by carbachol. The above morphological data help in understanding the route by which gastrointestinal peptides may appear in the intestinal lumen following stimulation, and sharply contrasts with the widely accepted unidirectional stimulus-secretion coupling hypothesis (Kanno and Imai, 1976). 
Interestingly, the regulatory peptides are detected in biologically active forms in the GIT lumen. Furthermore, all authors consistently emphasise that the peptide concentration in the gastrointestinal lumen or the calculated output into the lumen is greater than the respective venous concentration or output - both under control conditions and following stimulation (for review sec: Rao, 1991). In vitro studies reveal that, despite disadvantagcous conditions in the stomach and gut lumen (acidic $\mathrm{pH}$ values, and/or abundance of proteolytic enzymes), regulatory peptides and growth factors are remarkably stable in gastrointestinal fluids. Nevertheless, the survival of gut peptides is much better in the digestive juices collected from neonates than from adults (Shen and $\mathrm{Xu}, 1996$; Xu et al., 1996). The degradation rate of gastrin (G17 and G 34) incubated for $20 \mathrm{~min}$ in the intestinal juice collected from adult pigs is between 10 and 15\% (Xu et al., 1996) and that of EGF about $20 \%$ (Shen and $\mathrm{Xu}, 1996$ ). The addition of acid soluble or casein fractions of porcine colostrum to the intestinal fluids markedly reduces the degradation rate of gastrin and EGF. Read et al. (1987) reported that 60 to $90 \%$ of intragastrically administered EGF reached the small intestine in the intact form in new-born lambs. These data suggest that the biological half-life of regulatory peptides in the intestinal lumen may be much longer than in the blood plasma which strengthens their potential physiological relevance at the luminal site.

Luminal gastrins, cholecystokinins and secretin affect intestinal motility and absorption, exert trophic effects on enterocytes and stimulate pancreatic juice secretion in adult dogs and neonatal calves (Johnson et al., 1978; Chey et al., 1979; Sninsky et al., 1984; Schwartz and Storozuk, 1986; Zabielski et al., 1995). Luminal effects of CCK are reversed by intraduodenal administration of a poorly absorbed CCK-A receptor antagonist (Zabielski et al., 1996). Konturek et al. (1981) have found that luminal somatostatin can be reabsorbed by the intestine, circulate into the pancreas and inhibit its exocrine function which suggests that the lumen of the intestine may be an important link of enteropancreatic circulation of some regulatory peptides. Oral administration of insulin causes hypoglycaemia in pigs and calves (see revicw of Koldowsky et al., 1988), and subcutaneous administration of insulin speeds up gut closure in pig neonates (Svendsen et al., 1986). The growth factors manifest numerous local biological effects on the gut epithelium as well as peripheral effects following thcir absorption from the gut into the circulating blood. The latter is especially significant in neonates and wcancd young animals (Thornburg et al., 1984, 1987; Read et al., 1987). Thus, EGF inhibits gastric sccretion (Konturek et al., 1984) stimulates epithelial cell growth and cell differentiation (James et al., 1987; Thomburg and Koldovsky, 1987), and increases the specific activity of mucosal ornithine decarboxylase and the incorporation of labelled thymidine into DNA (Ulshen et al., 1986; Berseth, 1987b). IGFs exert similar effects on the gastrointestinal tract mucosa (Lemmey et al., 1991; Vanderhoof, 1992). Exogenous IGF-I prevents bacterial translocation in the GIT in rats with 
experimental burn injury (Huang et al., 1993). CDGF induces gene activation and cell growth in cultured intestinal cells in vitro (Kelly and Coutts, 1997).

\section{IMPORTANCE OF MILK BAPP FOR SUCKLING}

The effects of bioactive proteins and peptides delivered with milk have been studied by selective suppression of compounds in the maternal plasma (immunoncutralization, gene knock-out), by physical (heating, centrifugation) or biochemical pretreatment (trypsin and chymotrypsin pretreatment) of milk. Experiments with oral administration of single BAPP (often in unphysiologically high doses) and with pharmacological block of mucosal receptors (which may also influence endogenous factors) have also been employed. The review by Xu (1996) discusses a number of results that point to an important role for bioactive compounds in colostrum and milk in the development of the GIT. Although the experimental methods lcave room for doubt, the results are worth consideration. The deprivation of milk prolactin, insulin, growth hormone, CCK, EGF and IGF, slows growth and functional maturation of the GIT and peripheral tissues in neonates of different species (Berseth et al., 1983; Grosvenor et al., 1986; Berseth, 1987; Behringer et al., 1990; Xu et al., 1994; Wang and Xu, 1996; Mubiru, 1997; Zabielski et al., 1998). In bottle-fed neonate pigs, feeding with bovine colostrum results in a lower weight of the intestinal mucosa than feeding with sow colostrum (Tungthanathanich et al., 1992). Feeding new-born dogs with an artificial formula reduces the growth of the GIT, although it does not affect the body weight gain (Heird et al., 1984). Feeding pig neonates with colostrum devoid of insulin (by trypsin predigestion) inhibits maturation of intestinal enzymes (Wang and $\mathrm{Xu}, 1996$ ). Also, feeding piglets with an infant formula supplemented with IGF-I and IGF-II leads to a higher DNA content in the stomach and increases the cell proliferation in the upper gut as compared to an infant formula alone (Xu et al., 1994). Recently, the importance of IGF-l in rat and human milk has been questioned following reports that endogenous IGF-I may be produced in sufficient amounts and then taken up selectively by the proximal gut in the newborn (Burrin, 1997; Steeb et al., 1997).

Studies on late effects of single BAPP supplementation on human and animal health and performance are lacking. Numerous investigations, however, have been made comparing the effects of breast-feeding versus milk formula feeding in humans. Collingwood and Alberman (1979) in their questionnaire studies found that children who had been separated from their mothers immediately after birth, for a minimum period of 17 days, were more likely to have "poor health and appetite". Infants who had been breast-fed for up to 6 months have reduced risk of allergies, respiratory and gastrointestinal disorders, type I diabetes and childhood lymphomas compared to formula-fed infants (for references see: Zinn, 1997). Huffman 
and Combest (1990) revicwed the literature seeking interrelations between breastfeeding and morbidity and mortality from diarrhoea in infants in the developing countries. The outcome of their investigation is that non-breast-fed infants have a 25 -times greater risk of dying from diarrhoea than breast-fed infants. According to their study, early food supplementation leads to an increased risk of diarrhoea.

\section{BAPP AS FEED ADDITIVES ?}

In the majority of artificial milk formulas, growth factors, hormones and gut regulatory peptides are undetectable or present at very low concentrations compared to fresh milk. According to present knowledge, a physiological role of these bioactive substances in the development of young production animals cannot be completely ruled out. Even though BAPP deprivation from the neonate is apparently not lethal, it may increase the risk of certain gastrointestinal and other organ disorders. Moreover, some BAPP deficiencies (e.g., EGF, IGF-I) may be presumably compensated by the endocrine system of the neonate when this has developed. So, should we consider providing these BAPP as feed additives? It is perhaps premature to state ultimately that BAPPs should be provided as feed additives, the more so since at least two human generations and several dairy cattle generations have already grown up on a variety of artificial formulas which had certain BAPP deficits. However, during that time nutritional and hygienic standards have greatly improved thus reducing the risk of bacterial or metabolic disorders. The diet has also been better balanced for nutritional value and its composition has been enriched with a number of substances accelerating animal performance and reducing the risk of disease (minerals, vitamins, antibiotics, etc). Nevertheless, in the face of serious environmental problems caused by the intensive use of certain feed additives (e.g., zinc oxide, antibiotics) we should consider BAPP supplementation as a more physiological and environmentally friendly alternative to feed additives for young animals. We also need to modify the technologies used in preparing the artificial milk formulas, based usually on processed cow milk, in order to avoid/minimise the degradation of bioactive peptides, and to supplement the formula with certain bioactive substances according to the species-specific requirements. Namely, in the new formula preparations for infants the deficiency of IGF-I, EGF, prolactin and TGF should be considered. For the preterm infant, a supplementation of the artificial formula with IGF-I scems to be particularly important. Adamson and Reynolds (1995) have already suggested the utilisation on a commercial scale of the anticariogenic phosphopeptides released during casein digestion with pancreatin as a food additive, toothpaste and mouthwash for the prevention of dental caries in children. In the pig industry, attention should be paid to the time of weaning and milk production in the sow. In early weaned pigs, 
nutritional stimulation of GIT maturation as well as the addition of BAPP preparations to the weaned food need to be investigated. Neonatal calves should not be separated from their mothers within the first week of life, since this period is characterised by the highest BAPP concentration in milk. Calves should suckle their dams directly, since the treatment of colostrum and milk (cooling, storing and rewarming) reduces the level of BAPP. Pet neonates, e.g., dogs, should be fed with formulas that meet species-specific demands of the suckling young.

\section{ACKNOWLEDGEMENTS}

This work was supported by a grant from the Swedish Foundation for International Cooperation in Research and Higher Education (STINT, Dnr 97/560). The help of Dr. T. Ploszaj in the collection of bibliographical material is greatly acknowledged.

\section{REFERENCES}

Adamson N.J., Reynolds E.C., 1995. Characterization of multiply phosphorylated peptides selectively precipitated from a pancreatic casein digest. J. Dairy Sci. 78, 2653-2659

Ballard F.J., Nield M.K., Francis G.L., Dahlenburg G.W., Wallace J.C., 1982. The relationship between the insulin content and inhibitory effects of bovine colostrum on protein breakdown in cultured cells. J. Cell. Physiol. 110, 249-254

Baxter R.C., Zaltsman Z., Turtle J.R., 1984. Immunoreactive somatomedin-C/insulin-like growth factor I and its binding protein in human milk J. Clin. Endocrinol. Metab. 58, 955-959

Behringer R.R., Lewin T.M., Quaife C.J., Palmiter R.D., Brinster R.L., D'Ercole A., 1990. Expression of insulin-like growth factor I stimulates normal somatic growth in growth hormone-deficient transgenic mice. J. Endocrinol. 127, 1033-1040

Berseth C.L., 1987. Enhancement of intestinal growth in neonatal rats by epidermal growth factor in milk. Amer. J. Physiol. 253, G662-G665

Berseth C.L.. Lichtenberger L.M., Morris F.F., 1983. Comparison of the gastrointestinal growthpromoting effects of rat colostrum and mature milk in newborn rat in vivo. Amer. J. Clin. Nutr. $37,52-60$

Berthon P., Salmon H., 1993. Facteurs immunitaires des secretions mammaires. In: J. Martinet, L.M. Houdebine (Editors). Biologie de la lactation. INSERM/INRA, Paris, pp. 389-414

Björksten B., Burman L.G., de Chateau P., 1980. Collecting and banking human milk: to heat or not to heat? Brit. Med. J. $281,765-769$

Brandt R., Pepperle M., Otto A., Kraft R., Beohmer F.D., Grosse R., 1987. A 13-kilodalton protein purified from milk fat globule membranes is closely related to a mammary-derived growth inhibitor. Biochem J. 27, 1420-1425

Burrin D.G., 1997. Is milk-borne Insulin-like Growth Factor-I essential for neonatal development? J. Nutr. 127, 975S-979S

Chang T.M., Chey W.Y., Kim M.S., Lee K.Y., 1981. The release of biologically active secretin-like immunoreactivity into duodenal lumen of dogs. J. Physiol. 320, 393-401 
Chey W.Y., Kim M.S., Lee K.Y., Chang T.M., 1979. Effect of rabbit antisecretin serum on postprandial pancreatic secretion in dogs. Gastroenterology $77,1268-1275$

Collingwood J., Alberman E., 1979. Separation at birth and the mother-child relationship. Develop. Med. Child. Neurol. 21, 5, 608-618

Conlon J.M., Rouiller D., Boden G., Unger R.H., 1979. Characterization of immunoreactive components of insulin and somatostatin in canine pancreatic juice. FEBS Lett. 105, 23-26

Dawidson I., Blom M., Lundeberg T., Theodorsson E., Angmar-Mansson B., 1997. Neuropeptides in the saliva of healthy subjects. Life Sci, 60, 269-278

Ekman R., Ivarsson S., Jansson L., 1985. Bombesin, neurotensin and pro-gamma-melanotropin immunoreactans in human milk. Regul, Peptides 10, 99-105

Erwin Jr. P.R., Kaminski M.S., Cody R.C., Wicha M.S., 1989. Production of mammastatin, a tissue specific growth inhibitor, by normal human mammary cells. Science $244,1585-1587$

Fujimiya M., Okumiya K., Maeda T., 1995. Immuno-electron microscopic demonstration of luminal release of serotonin from enterochromaffin cells of rat embryo. Acta Histochem. Cytochem 28, $555-563$

Grongnet J.F., Duvaux-Ponter C., 1998. Acquisition of passive immunity in domestic ungulates. J. Animal. Feed Sci. 7, 93-114

Grosvenor C.E., Picciano M.F., Baumrucker C.R., 1992. Hormones and growth factors in milk. Endocr. Rev. 14, 710-728

Grosvenor C.E., Shyr S.W., Crowley W.R., 1986. Effect of neonatal prolactin deficiency on prepubertal tuberoinfundibular and tuberophyseal dopaminergic neuronal activity. Endocr. Exp. 20, 223-228

Guimont C., Marchall E., Girardet J.M., Linden G., 1997. Biologically active factors in bovine milk and dairy byproducts: influence on cell culture. Crit, Rev. Food Sci. Nutr. 37, 393-410

Heird W.C., Schwartz S.M., Hansen I.H., 1984. Colostrum-induced enteric mucosal growth in beagle puppies. Pediat. Res. 18, 512-515

Huang K.F., Chung D.H., Herndon D.N., 1993. Insulin-like growth factor-1 (IGF-1) reduces gut atrophy and bacterial translocation after severe burn injury. Arch. Surg. 128, 47-54

Huffman S.L., Combest C., 1990. Role of breast-feeding in the prevention and treatment of diarrhoea. J. Diarrhoeal Dis. Res. 8, 3, 68-81

Iacopetta B.J., Grieu F., Horisberger M., Sunahara G.I., 1992. Epidermal growth factor in human and bovine milk. Acta Pediatr. 81, 287-291

Jaeger M.A., Lamar C.H., Bottoms G.D., Cline T.R., 1987. Growth-stimulating substances in porcine milk. Amer. J. Vet. Res. 87, 1531-1533

James P.S., Smith M.W., Tivey D.R., Wilson T.J.G., 1987. Epidermal growth factor selectively increases maltase and sucrase activities in neonatal piglet intestine. J. Physiol. 393, 583-594

Johnson R.F., Copeland E.M., Dudrick S.J., 1978. Luminal gastrin stimulates growth of the distal rat intestine. Scand. J. Gastroenterol. 13, Suppl. 49, 95

Jordan P.H., Yip B.S., 1972. The presence of gastrin in fasting and stimulated gastric juice of man. Surgery $72,352-356$

Kanno T., Imai S., 1976. Stimulus-secretion coupling in the cell secreting cholecystokinin-pancreozymin. In: T. Fujita (Editor). Endocrine gut and pancreas. Elsevier Scientific Publishing Company, Amsterdam, pp. 245-254

Kelly D., Coutts A.P.G., 1997. Biologically active peptides in colostrum and milk. In: J.P. Laplace, C. Fevrier, A. Barbeau (Editors). Digestive physiology in pigs. EAAP Publication No. 88, pp. $163-170$

Ken-Dror S., Weintraub Z., Yechiely H., Kahana L., 1997. Atrial natriuretic peptide and endothelin concentrations in human milk during postpartum lactation. Acta Pediatr. 86, 793-795 
Koldovsky O., Bedrick A., Pollack P., Rao R.K., Thomburg W., 1988. Biology of human milk: possible physiological role of hormones and hormone related substances present in milk. Nestle Nutrition Workshop Series, Vol 15. L.A. Hanson (Editor). Nestle Lid, Vevey/Raven Press, Ltd., New York, pp. 123

Koldowsky O., Illnerova, H., Macho L., Strbak V., Stepankova R., 1995. Milk-borne hormones: possible tools of communication between mother and suckling. Physiol. Res. 44, 349-351

Konturek S.J., Cicszkowski M., Jaworek J., Konturek J., Brzozowski T., Gregory H., 1984. Effects of epidermal growth factor on gastrointestinal secretions. Amer. J. Physiol. 246, G580 - G586

Konturek S.J., Tasler J., Cieszkowski M., Jaworek J., Arimura A., Schally A.V., 1981. Studies on the inhibition of pancreatic secretion by luminal somatostatin. Amer. J. Physiol., 241, G109-G115

Kuvishnoff B.W., Rudnicki M., McFadden D.W., 1991. The effect of SMS-995 on meal and CCK stimulated peptide YY release. J. Surg. Res. 50, 425 - 429

Lam H.C., Takahsi K., Ghatei M.A., Warrens A.N., Rees A.J., Bloom S.R., 1991. Immunoreactive endothelin in human plasma, urine, milk and saliva. J. Cardiovasc. Pharmacol. 17 (7), 390-393

Lemmey A.B., Martin A.A., Read L.C., Tomas F.M., Owens P.C., Ballard F.J., 1991. IGF-I and the truncated analogue des-( $1-3)$ IGF-I enhance growth in rats after gut resection. Amer. J. Physiol. 260, E213-E219

Malven P.V., Head H.H., Collier R.J., Buonomo F.C., 1987. Periparturient changes in secretion and mammary uptake of insulin and in concentrations of insulin and insulin-like growth factors in milk of dairy cows. J. Dairy Sci. 70, 2254-2265

McCrae C.H., Muir D.D., 1995. Heat stability of milk. IDF, 10, 206-230

Meisel H., 1997. Biochemical properties of bioactive peptides derived from milk proteins: potential nutraceuticals for food and pharmaceutical applications. Livest. Prod. Sci. 50, 125-138

Miller L.J., Go V.L.W., 1980. Radioimmunoassay of cholecystokinin and gastric inhibitory peptide. In: G.B.G. Glass (Editor). Gastrointestinal hormones. Raven Press, New York, pp. $863-864$

Mubiru J. N., 1997. Growth and development of the pancreas and stomach in neonatal pigs. Ph.D. dissertation. University of Hong Kong, Hong Kong

Murakami H., 1989. Senum-free media used for cultivation of hybridomas. In: Liss A.R. (Editor). Monoclonal antibodies: Production and application, pp. 107-141

Nagashima K., Itoh K., Kuroume T., 1990. Levels of insulin-like growth factor I in full- and preterm human milk in comparison to levels in cow's milk and in milk formulas. Biol. Neonate 58, 343-346

Odumodu C.U., Alford E.S., Diss C.W., Richter R.L., Garza C., 1993. Heat inactivation of the alkaline phosphatase in human milk and colostrum. J. Food Protection, 56, 260-262

Okumiya K., Matsubayashi K., Maeda T., Fujimiya M., 1996. Change in subcellular localization of gastrin-like immunoreactivity in epithelial cclls of rat duodenum induced by carbachol. Peptides 17, 225-232

Puyol P., Perez M.D., Peiro J.M., Calvo M., 1994. Effect of binding of retinol and palmitic acid to bovine b-lactoglobulin on its resistance to thermal denaturation. J. Dairy Sci. 77, 1494-1502

Raadberg L., Nexo E., Tollund L., Poulsen S.S., Christensen S.B., Christensen M.S., 1990. Epidermal growth factor reactivity in rat milk. Regul. Peptides 30, 149-157

Rao R.K., 1991. Biologically active peptides in the gastrointestinal lumen. Life Sci. 48, 1685-1704

Rao R.K., Koldovsky O., Davis T.P., 1990. Inhibition of intestinal degradation of somatostatin by rat milk. Amer. J. Physiol. 258, G426-G431

Read L.C., 1988. Milk growth factors. In: F. Cockburn (Editor). John Wiley and Sons, London, pp. $131-152$

Read L.C., Gale S.M., George-Nascimento C., 1987. Intestinal absorption of epidermal growth factor in newborn lambs. In: A.S. Goldman. S.A. Atkinson, L.A. Hanson (Editors). Human lactation. 3. The effects of human milk on the recipient infant. Plenum Press, New York, pp. 199-204 
Read L.C., Upton F.M., Francis G.L., Wallace J.C., Dahlenberg G.W., Ballard F.J., 1984. Changes in the growth-promoting activity of human milk during lactation. Pediat. Res. 18, 133-139

Read L.C., Upton F.M., Francis G.L., Wallace J.C., Dahlenberg G.W., Ballard F.J., 1985. Growth factor concentrations and growth-promoting activity of human milk following premature birth. J. Develop. Physiol. 7, 135-145

Rudloff S., Kunz C., 1997. Protein and nonprotein nitrogen components in human milk, bovine milk, and infant formula: quantitative and qualitative aspects in infant nutrition. J. Pediat. Gastroenterol. Nutr, 24, 328-344

Rudloff S., Lönnerdal B., 1992a. Calcium and zinc retention from protein hydrolysate formulas in suckling Rhesus monkeys. Amer. J. Dis. Child 146, 588-591

Rudloff S., Lönnerdal B., 1992b. Solubility and digestibility of milk proteins in infant formulas exposed to different heat treatments. J. Pediat. Gastroenterol. Nutr. 15, 25-33

Schanbacher F.L., Talhouk R.S., Murray F.A., 1997. Biology and origin of bioactive peptides in milk. Livest. Prod. Sci. 50, 105-123

Schwartz M.Z., Storozuk R.B., 1986. Enhancement of small intestinal absorption by intraluminal gastrin. J. Surg. Res. 40, 421-425

Shen W.H., Xu R-J., 1996. Stability of epidermal growth factor in the gastrointestinal lumen of suckling and weaned pigs. Life Sci. 59, 197-208

Silberstein G.B., Daniel C.W., 1987. Reversible inhibition of mammary gland growth by transforming growth factor-b. Science 237, 291-293

Sninsky C.A., Wolfe M.M., McGuigan J.E., Mathias J.R., 1984. Alterations in motor function of the small intestine from intravenous and intraluminal cholecystokinin. Amer. J. Physiol. 247, G724-G728

Steeb C.B., Shoubridge C.A., Tivey D.R., Read L.C., 1997. Systemic infusion of IGF-I or LR3IGF- I stimulates visceral organ growth and proliferation of gut tissues in suckling rats. Amer. J. Physiol. 272, G522-G533

Strbak V., Alexandrova M., Macho L., Ponec J., 1980. Transport of 3H-TRH from plasma to rat milk: accumulation and slow degradation in milk and presence of unaltered hormone in gastric content of pups. Biol. Neonate 37, 313-321

Svendsen L.S., Weström B.R., Svendsen J., Ohlsson B.G., Ekman R., Karlsson B.W., 1986. Insulin involvement in intestinal macromolecular transmission and closure in neonatal Pigs. J. Pediat. Gastroenterol. Nutr. 5, 299-304

Thornburg W., Koldovsky O., 1987. Growth factors in milk: their effect on the developing gastrointestinal tract. In: N. Kretchmer, E.J. Qilligan, J.D. Johnson (Editors). Prenatal and perinatal biology and medicine, Vol. 1. Physiology and growth. Harwood Academic Publisher, Chru, Switzerland, pp. 161-177

Thornburg W., Matrisian L., Magun B., Koldovsky O., 1984. Gastrointestinal absorption of epidermal growth factor in suckling rats. Amer. J. Physiol. 246, G80-G85

Thornburg W., Rao R.K., Matrisian L.M., Magun B.E., Koldovsky O., 1987. Effect of maturation on gastrointestinal absorption of epidermal growth factor in rats. Amer. J. Physiol. 16, G68-G71

Tirelli A., DeNoni I., Resmini P., 1997. Bioactive peptides in milk products. Italian J. Food. Sci. 9, 91-98

Toth B.E, Kacsoh B., Yamamuro Y., Avery L.M., Grosvenor C.E., 1992. Rat milk inhibits the mitogenic response of $\mathrm{Nb} 2$ cells to prolactin. Endocr. Regul. 25, 120-127

Tungthanathanich P., Xu R-J., Reynolds G.W., Simpson H.V., Mellor D.J., 1992. The effect of milk diets on small intestinal growth in newborn piglets. Proc. Nutr. Soc. N.Z. 17, 51-55

Ulshen M.H., Lyn-Cook L.E., Raash R., 1986. Effects of intraluminal epidermal growth factor on mucosal proliferation in the small intestine of adult rats. Gastroenterology $91,1134-1140$ 
Vanderhoof J.A., McCusker R.H., Clark R., Mohammadpour H., Blackwood D.J., Harty R.F., Park J.Y.H., 1992. Truncated and native insulin-like growth factor I enhance mucosal adaptation after jejunoileal resection. Gastroenterology 102, 1949-1956

Vardri A., 1993. Biological roles of oligosaccharides: all of the theories are correct. Glycobiology 3, 97-130

Wang T., Xu R.J., 1996. Effect of colostrum feeding on intestinal development in newborn pigs. Biol. Neonate 70, 339-348

Weström B.R., Ekman R., Svendsen L., Svendsen J., Karlsson B.W., 1987. Levels of immunoreactive insulin, neurotensin, and bombesin in porcine colostrum and milk. J. Pediat. Gastroenterol. Nutr. 6, 460-465

Wong D.W.S., Camirand W.M., Pavlath A.E., 1996. Structures and functionalities of milk proteins. Crit. Rev. Food Sci. Nutr. 36, 807-844

Xu R-J., 1996. Development of the newborn Gl tract and its relation to colostrum/milk intake: a Review. Reprod. Fertil. Dévelop. 8, 35-48

Xu R-J., Mao Y.L., Tso M.Y.W., 1996. Stability of gastrin in the gastrointestinal lumen of suckling, weanling and adult pigs. Biol. Nconate 70, 60-68

Xu R-J., Mellor D.J., Birtles M.J., Brier B.H., Gluckman P.D., 1994. Effects of oral IGF-I or IGF-II on digestive organ growth in newborn piglets. Biol. Neonate $66,280-287$

Zabielski R., Leśniewska V., Kiela P., Gregory P.C., Pierzynowski S.G., 1996. Intraduodenal administration of cholecystokinin-A receptor blocker (Tarazepide) reduces secretion of pancreatic juice in newborn calves. Regul. Peptides 64, 213

Zabielski R., Onaga T., Mineo H., Kato S., Pierzynowski S.G., 1995. Intraduodenal cholecystokinin octapeptide (CCK-8) can stimulate pancreatic secretion in the calf. Int. J. Pancreatol. 17, 271-278

Zabielski R., Podgumiak P., LeHuerou-Luron Guilloteau P., 1998. Secretion of pancreatic juice in the first week of life in calves. Role of FK480. Digestion (in press)

Zinn S.A., 1997. Bioactive components in milk: introduction. Livest. Prod. Sci. 50, 101-103 